\title{
Pengaruh Motivasi Belajar Dan Kecerdasan Spiritual Terhadap Pelaksanaan Program Tahfidz Al-Qur'an Di SMP Negeri 1 Wungu Kabupaten Madiun
}

\author{
Alfin Taufik Almujab, ${ }^{1}$ Moch. Mukhlison ${ }^{2}$ \\ ${ }_{1}$ Pascasarjana Institut Agama Islam Tribakti Kediri, ${ }^{2}$ Institut Agama Islam Tribakti Kediri \\ 1alfitamujab@gmail.com,2moch.mukhlison89@gmail.com
}

\begin{abstract}
The implementation of the Tahfidz Al Qur'an program referred to in this study is a process or effort to remember the verses of the Holy Qur'an in memory and be able to maintain memorization of at least one juz during studying in grades 7 and 8 for students who take the Tahfidz program Al Qur'an in SMP Negeri 1 Wungu, Madiun Regency. The success or failure of the implementation of the Tahfidz Al Qur'an program is influenced by several factors, including learning motivation and spiritual intelligence. This research is a quantitative research. The population in this study were all students who took part in the Tahfidz program at SMP Negeri 1 Wungu, Madiun Regency, totaling 72 students. Data collection techniques use documentation, interviews and questionnaires. Data analysis techniques using multiple linear analysis, $t$ test, F test, coefficient of determination, which is preceded by the assumption of the analysis test that is normality test and linearity test. The results of this study indicate that: 1) There is a significant positive effect on learning motivation towards the implementation of the Tahfidz Al Qur'an program. 2) There is a significant positive influence of spiritual intelligence on the implementation of the Tahfidz Al-Qur'an program. 3) There is a significant positive effect of learning motivation and spiritual intelligence together on the implementation of the Tahfidz Al Qur'an program.
\end{abstract}

Keywords: Learning Motivation, Spiritual Intelligence, Tahfidz Qur'an Program

\begin{abstract}
Abstrak
Pelaksanaan program Tahfidz Al Qur'an yang dimaksud dalam penelitian ini adalah proses atau usaha untuk mengingat ayat-ayat suci Al Qur'an dalam ingatan dan mampu mempertahankan hafalan tersebut minimal satu juz selama menempuh pendidikan di kelas 7 dan 8 bagi siswa yang mengikuti program Tahfidz Al Qur'an di SMP Negeri 1 Wungu Kabupaten Madiun. Berhasil tidaknya pelaksanaan program Tahfidz Al Qur'an dipengaruhi oleh beberapa faktor, diantaranya adalah motivasi belajar dan kecerdasan spiritual. Penelitian ini merupakan penelitian kuantitatif. Populasi dalam penelitian ini semua siswa yang mengikuti program tahfidz di SMP Negeri 1 Wungu Kabupaten Madiun yang berjumlah 72 siswa. Adapaun teknik pengumpulan data menggunakan dokumentasi, wawancara, dan angket. Teknik analisis data menggunakan analisis linier berganda, uji t, uji F, koefisiensi determinasi,
\end{abstract}


yang didahului dengan uji asumsi analisis yaitu uji normalitas dan uji linieritas. Hasil penelitian ini menunjukkan bahwa: 1) Ada pengaruh positif yang signifikan motivasi belajar terhadap pelaksanaan program Tahfidz Al Qur'an. 2) Ada pengaruh positif yang signifikan kecerdasan spiritual terhadap pelaksanaan program Tahfidz Al-Qur'an. 3) Ada pengaruh positif yang signifikan motivasi belajar dan kecerdasan spiritual secara bersama-sama terhadap pelaksanaan program Tahfidz Al Qur'an.

\section{Kata Kunci: Motivasi Belajar, Kecerdasan Spiritual, Program Tafidz Al Qur'an}

\section{Pendahuluan}

Setiap individu memiliki kondisi internal yang turut berperan dalam aktivitas dirinya sehari-hari. Salah satu dari kondisi internal tersebut adalah "motivasi". Motivasi adalah dorongan dasar yang menggerakkan seseorang bertingkah laku. Motivasi adalah kekuatan, baik dari dalam maupun dari luar yang mendorong seseorang untuk mencapai tujuan tertentu yang telah ditetapkan sebelumnya. Motivasi juga dapat dikatakan sebagai perbedaan antara dapat melaksanakan dan mau melaksanakan. ${ }^{1}$

A. W. Bernard memberikan pengertian motivasi sebagai fenomena yang dilibatkan dalam perangsangan tindakan ke arah tujuan-tujuan tertentu. ${ }^{2}$ Yamin mengemukakan bahwa motivasi belajar merupakan daya penggerak psikis dari seseorang untuk dapat melakukan kegiatan belajar dan menabmbahkan keterampilan, pengalaman. Motivasi

${ }^{1}$ Hamzah. B. Uno, Teori Motivasi EPengukurannya Analisis di Bidang Pendidikan: Analisis di Bidang Pendiddikan, (Jakarta: Bumi Aksara, 2014), h. 1.

2 Purma Atmaja Prawira, Psikologi Pendidikan dalam Perspektif Baru, (Yogyakarta: Ar Ruz Media, 2012), h. 319 mendorong dan mengarah minat belajar untuk mencapai satu tujuan. Siswa akan bersungguh-sungguh belajar karena termotivasi mencapai prestasi, mendapatkan kedudukan dalam jabatan, menjadi politekus, dan memecahkan masalah. ${ }^{3}$

Siswa yang memiliki motivasi kuat, akan mempunyai banyak energi untuk belajar. Keberhasilan belajar siswa dapat ditentukan oleh motivasi belajar yang dimilikinya. Siswa yang memiliki motivasi belajar tinggi cenderung prestasinya pun akan tinggi pula, sebaliknya siswa yang motivasinya rendah, akan rendah pula prestasi belajarnya. Seorang siswa yang memiliki inteligensia yang tinggi, bisa saja gagal karena kekurangan motivasi. Prestasi belajar akan optimal kalau memiliki motivasi yang tepat. ${ }^{4}$

Spiritual Quotien (SQ) atau kecerdasan spiritual merupakan temuan mutakhir secara ilmiah yang pertama kali

\footnotetext{
${ }^{3}$ Martinis Yamin, Strategi Pembelajaran Berbasis Kompetensi, (Ciputat: Gaung Persada Press, 2003),

${ }^{4}$ Sardiman A.M. , Interaksi \& Motivasi Belajar Mengajar, (Jakarta: Raja Grapindo Persada, 2010),
} h. 80. h. 75 . 
digagas oleh Danah Zohar dan Ian Marshall, masing-masing dari Harvard University dan Oxford University melalui serangkaian penelitian yang sangat komprehensif. Mereka mendefinisikan kecerdasan spiritual sebagai kecerdasan untuk menghadapi persoalan makna atau value, yaitu kecerdasan untuk menempatkan perilaku dan hidup dalam konteks makna yang lebih luas dan kaya, kecerdasan untuk menilai bahwa tindakan atau jalan hidup seseorang lebih bermakna dibandingkan dengan yang lain. ${ }^{5}$

Membahas perkembangan anak, kecerdasan spiritual mencakup pengembangan kesadaran untuk membina hubungan dengan orang lain secara etis, bermoral dan manusiawi. Di dalamnya termasuk pula pemahaman akan nilainilai (seperti nilai kejujuran dan hormat) serta pemahaman akan konsep lain, seperti konsep "benar dan salah" dan konsep "konsekuensi dan tanggung jawab". 6

Desmita dalam buku psikologi perkembangan, menyebutkan bahwa anak-anak telah memilki dasar-dasar kemampuan SQ yang dibawanya sejak lahir. Untuk mengembangkan kemampuan ini, pendidikan mempunyai peran peran yang sangat penting. Oleh karena itu, untuk melahirkan manusia yang ber-

5 Ary Ginanjar Agustian, Rahasia Sukses Membangun Kecerdasan Emosi dan Spiritual (ESQ), (Jakarta: Penerbit Arga, 2001), h. 57.

6 Carolyn Meggit, Memahami Perkembangan Anak, (Jakarta: PT Indeks, 2013), h. 16.

7 Desmita, Psikologi Perkembangan, (Bandung:
SQ tinggi, dibutuhkan pendidikan yang tidak hanya memperhatikan pengembangan aspek IQ saja melainkan sekaligus EQ dan SQ. ${ }^{7}$

Menurut psikologi perkembangan, anak usia sekolah dasar terbagi menjadi dua periode, yaitu masa anak tengah (usia 7-9 tahun) dan masa anak akhir (1012 tahun). Pada masa ini, anak mulai memiliki perspektif yang berbeda dengan orang lain yang berada di sekitarnya. Orang tua sering menganggap periode ini sebagai masa sulit karena anak menjadi susah diatur, bisa disebut nakal atau bandel, suka membantah dan banyak bertanya. ${ }^{8}$

Sukidi dalam bukunya Rahasia Sukses Hidup Bahagia Kecerdasan Spiritual, memaparkan bahwa dewasa ini telah marak fenomena krisis manusia, baik berupa krisis intelektual maupun moral. Jika ditarik lebih dalam lagi, krisis moral hampir merambah ke seluruh lini kehidupan, yang sebenarnya bermuara pada krisis spiritual yang bercokol dalam diri manusia. ${ }^{9}$ Pemaparan tersebut menjelaskan adanya perilaku menyimpang pada anak-anak dan remaja mengindikasikan rendahnya kecerdasan spiritual yang dimilikinya.

Al Qur'an adalah kalam Allah SWT yang diturunkan kepada Nabi Muhammad SAW -yang merupakan

\footnotetext{
8 Ahmad Susanto, Perkembangan Anak Usia Dini, (Jakarta: Kencana, 2011), h. 49.

9 Sukidi, Rahasia Sukses Hidup Bahagia Kecerdasan Spiritual mengapa SQ lebih Penting daripada IQ dan EQ, (Jakarta: PT Gramedia Pustaka Utama, 2002), h. 4 .
} 
mukjizat- melalui perantara malaikat Jibril untuk disampaikan kepada umat manusia sebagai pedoman hidup sehingga umat manusia mendapat petunjuk untuk kebahagiaan hidup di dunia dan akhirat. ${ }^{10}$ Dalam surat Al-Isra ayat 106 telah diterangkan proses turunnya Al-Qur`an:

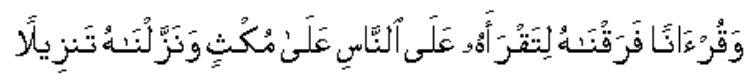

Terjemahannya: “Dan Al-Qur'an itu telah Kami turunkan dengan berangsur-angsur agar kamu membacakannya perlahanlahan kepada manusia dan Kami menurunkannya bagian demi bagian". ${ }^{11}$

Mengenal Al-Qur'an sejak dini merupakan langkah yang utama dan pertama sebelum pembelajaran lainnya. Bagi setiap keluarga muslim menanamkan nilai-nilai Al-Qur'an dalam rumah tangga sudah menjadi komitmen yang universal, sehingga terdapat waktu yang khusus untuk mengajar Al-Qur'an baik dilakukan oleh orang tua sendiri ataupun lembaga-lembaga pendidikan yang ada disekitarnya.

Fungsi utama Al-Qur'an adalah sebagai hidayah (petunjuk) bagi manusia dalam mengelola hidupnya di dunia secara baik, dan merupakan rahmat untuk alam semesta, di samping pembeda antara yang hak dan yang batil, juga sebagai penjelas terhadap sesuatu, akhlak, moralitas, dan etika-etika yang patut dipraktikkan manusia dalam hehidupan mereka. Penerapan semua ajaran Allah itu akan membawa dampak positif bagi manusia sendiri. ${ }^{12}$

Al-Qur'an diturunkan untuk dijadikan petunjuk, bukan hanya untuk sekelompok manusia ketika ia diturunkan, tetapi juga untuk seluruh manusia hingga akhir zaman. ${ }^{13}$ Sebab itu, untuk menjaga keautentikan Al-Qur'an diperlukan penjagaan dan pemeliharaan agar umat Islam tidak kehilangan petunjuk, yaitu dengan membumikan AlQur'an.

Membumikan Al-Qur'an di sini mempunyai maksud melalukan upayaupaya terarah dan sistematis di dalam masyarakat agar nilai-nilai Al-Qur'an hidup dan dipertahankan. ${ }^{14}$ Terdapat banyak cara dalam mempelajari dan membumikan Al- Qur'an, salah satunya yaitu dengan metode hafalan.

Mengajarkan anak-anak untuk menghafal Al-Qur'an adalah satu hal yang penting dan mulia. ${ }^{15}$ Al-Hafizh AsSuyuti berkata bahwa pengajaran alQur'an adalah dasar dari prinsip- prinsip Islam. Anak-anak tumbuh di atas fitrahnya dan cahaya- cahaya hikmah yang masuk ke dalam kalbu mereka sebelum dikuasai oleh hawa nafsu dan

12 Rif'at Syauqi Nawawi, Kepribadian Qur'ani, (Jakarta: Amzah, 2011), h. 240.

13 Rif'at Syauqi, h. 273.

14 Rif'at Syauqi, h. 274.

15 Sa'ad Riyadh, Anakku, Cintailah Al-Qur'an, (Jakarta: Gema Insani, 2009), h. 17. 
cahaya hitamnya yang dilekati kotorankotoran maksiat dan kesesatan. ${ }^{16}$

SMP Negeri 1 Wungu merupakan salah satu lembaga pendidikan di Kabupaten Madiun yang bertempat di jl. Raya Kare Kelurahan Wungu Kecamatan Wungu. SMP 1 Wungu mempunyai beberapa program ektrakurikuler, antara lain OSIS, pramuka, PMR, bela diri INKAI, futsal, badminton, voly, hidroponik, hadrah, qira'ah, dan program Tahfidz Al Qur'an. Meskipun dengan latar belakang sekolah umum program tahfidz merupakan program unggulan yang dimulai dari tahun pelajaran 2017-2018 semester ganjil. Program Tahfidz Al Qur'an di SMP 1 Wungu diikuti oleh siswa kelas 7 dan 8 yang berminat untuk mengikuti program tersebut dan menargetkan siswa mampu menghafal minimal 1 juz selama menempuh pendidikan di kelas 7 dan 8 . Program ini menggunakan metode khusus yang disesuaikan dengan tingkat umur dan psikologi anak, yakni menggunakan metode wahdah, metode sima'i dan metode jama'. Kegiatan Tahfidz Al Qur'an dilaksanakan setiap hari selasa sampai dengan hari kamis dimulai pukul 06.30 WIB sebelum kegiatan pembelajaran dimulai, sedangkan setoran hafalan dilakukan pada hari jum'at dan sabtu. Pelaksanaan program ini dilakukan dalam beberapa tahap yang telah disusun oleh guru Pendidikan

16 Ahmad Salim Badwilan, Panduan Cepat menghafal Al-Qur'an, (Jogjakarta: DIVA Press, 2009), h. 229-230.

17 S. Arikunto, Manajemen Penelitian. Jakarta:
Agama Islam. Tujuan daripada program Tahfidz Al Qur'an yakni untuk menciptakan generasi pecinta $\mathrm{Al}$ Qur'an sejak dini.

\section{Metode}

Penelitian ini merupakan jenis penelitian deskriptif kuantitatif, karena peneliti berusaha memperoleh data informasi yang berkaitan dengan fenomena yang diamati secara apa adanya. ${ }^{17}$ Artinya peneliti berusaha untuk mendeskripsikan data yang ada di SMP Negeri 1 Wungu Kabupaten Madiun yaitu dengan memaparkan hubungan faktor-faktor dengan beberapa variabel. Prosedur pemecahan masalah pada metode ini adalah dengan cara menggambarkan objek penelitian pada saat keadaan sekarang berdasarkan faktafakta sebagaimana adanya, kemudian dianalisis dan diinterpretasikan, bentuknya berupa survey dan studi perkembangan. ${ }^{18}$ Pendekatan yang digunakan dalam penelitian ini adalah pendekatan kuantitatif.

Penelitian ini mengkaji pengaruh motivasi belajar dan kecerdasan spiritual di SMP Negeri 1 Wungu Kabupaten Madiun sebagai variable bebas, sedangkan pelaksanaan program tahfidz Al-Qur'an di SMP Negeri 1 Wungu Kabupaten Madiun sebagai variabel terikat.

18 Syofian. Siregar. Metode Penelitian Kuantitatif. Jakarta: Prenadamedia Group. 2013. hal. 8 
Populasi penelitian ini adalah semua siswa yang mengikuti program tahfidz di SMP Negeri 1 Wungu Kabupaten Madiun yang berjumlah 72 siswa.

Sample adalah bagian dari jumlah dan karakteristik yang dimiliki oleh populasi tersebut. Bila populasi besar, dan peneliti tidak mungkin mempelajari semua yang ada pada populasi, maka peneliti dapat menggunakan sampel yang diambil dari populasi itu. ${ }^{19}$

Instrument dalam penelitian ini adalah pedoman dokumentasi dan pedoman angket. Pedoman dokumentasi adalah daftar yang berisikan patokanpatokan atau panduan dalam menelusuri sebuah dokumentasi. 20 Patokan dalam menelusuri dokumentasi ini adalah dokumen raport tahfidz semester genap tahun ajaran 2018-2019.

Analisa data setelah diperoleh instrument yang valid dan reliable merupakan proses penyederhanaan data dalam bentuk yang lebih mudah dipahami dan diinterpretasikan untuk mencari makna dan implikasi yang lebih luas dari hasil penelitian. Dalam mendeskripsikan data tentang motivasi belajar, kecerdasan spiritual dan pelaksanaan program tahfidz Al-Qur'an menggunakan uji statistic dengan metode regresi linier ganda, yang merupakan

19 Ibid, hal. 216.

${ }^{20}$ Ibid.

21 A. Jauhar Fuad and Agus Eko Sujianto, Analisis Statistik Dengan Program SPSS (Tulungagung: Cahaya Abadi, 2014) pengembangan dari regresi linier sederhana, yaitu sama-sama alat untuk mengetahui pengaruh satu atau lebih variabel bebas (independent) terhadap satu variabel terikat (dependent). Dengan menggunakan SPSS. ${ }^{21}$

\section{Kajian Teoritik \\ Pengertian Motivasi Belajar}

Belajar menurut Morgan dan kawan-kawan adalah perubahan tingkah laku yang relatif tetap dan terjadi sebagai hasil latihan atau pengalaman. ${ }^{22}$ Senada dengan yang diungkapkan Sardiman bahwa belajar merupakan perubahan tingkah laku atau penampilan dengan serangkaian kegiatan. ${ }^{23}$

Motivasi belajar merupakan salah satu faktor yang turut menentukan efektivitas pembelajaran. Callahan dan Clark mengemukakan bahwa motivasi merupakan tenaga pendorong atau penarik yang menyebabkan munculnya tingkah laku ke arah suatu tujuan tertentu. Peserta didik akan belajar dengan sungguh-sungguh apabila memiliki motivasi yang tinggi. ${ }^{24}$

Jadi motivasi belajar adalah kondisi psikologis yang mendorong seseorang untuk belajar dengan sunguh-sungguh yang pada waktunya akan berbentuk cara belajar yang sistematis, penuh konsentrasi dan dapat menyeleksi kegiatan-kegiatannya. Setiap manusia

${ }^{22}$ Baharuddin dan Esa Nur Wahyuni, "Teori Belajar dan Pembelajaran", (Yogyakarta: Ar Ruz Media, 2015), h. 16.

${ }^{23}$ Sardiman, , h. 112.

${ }^{24}$ E. Mulyasa, Kurikulum Berbasis Kompetensi Konsep Karakteristik dan Implementasi, (Bandung: PT. Remaja Rosdakarya, 2002), h. 112. 
memiliki kebutuhan-kebutuhan yang secara sadar atau tidak berusaha untuk mewujudkannya. Hal ini menunjukkan bahwa kebutuhan merupakan awal timbulnya suatu motivasi yang mampu menggerakkan perilaku tersebut.

\section{Faktor-faktor yang Mempengaruhi Motivasi Belajar}

Menurut Dimyati dan Mudjiono ada beberapa faktor yang mempengaruhi motivasi belajar, yaitu:

\section{Cita-cita atau Aspirasi Siswa}

Cita-cita dapat belangsung dalam waktu sangat lama, bahkan sepanjang hayat. Cita-cita siswa untuk "menjadi seseorang" akan memperkuat semangat belajar dan mengarahkan pelaku belajar. Cita-cita akan memperkuat motivasi belajar intrinsik maupun ekstrinsik sebab tercapainya suatu cita-cita akan mewujudkan aktualisasi diri.

\section{Kemampuan Belajar}

Dalam belajar dibutuhkan berbagai kemampuan. Kemampuan ini meliputi beberapa aspek psikis dang terdapat dalam siswa. Misalya pengamatan, perhatian, ingatan, daya pikir dan fantasi.

Di dalam kemampuan belajar ini, sehingga perkembangan berpikir siswa menjadi ukuran. Siswa yang taraf perkembangan fikirnya konkrit (nyata) tidak sama dengan siswa yang berpikir secara operasional. Jadi siswa yang mempunyai kemampuan belajar tinggi biasanya lebih termotivasi dalam belajar, karean siswa seperti itu lebih sering memperoleh sukses karena sukses memperkuat motivasinya.
Siswa adalah makhluk yang terdiri dari kesatuan psikofisik. Jadi kondisi siswa yang mempengaruhi motivasi belajar di sini berkaitan dengan kondisi fisik dan psikologis, tetapi biasanya guru lebih cepat melihat kondisi fisik, karena lebih jelas menunjukkan gejalanya daripada kondisi psikologis. Misal siswa kelihatan lesu, mengantuk mungkin juga karena malam harinya ia begadang atau sakit.

4. Kondisi Lingkungan Kelas

Kondisi lingkungan merupakan unsur yang datang dari luar siswa. Lingkungan siswa sebagaimana juga lingkungan individu pada umumnya ada tiga lingkungan yaitu keluarga, sekolah dan masyarakat.

Jadi unsur-unsur yang mendukung atau menghambat kondisi lingkungan berasal dari ketiga lingkungan tersebut. Hal ini dapat dilakukan misalnya dengan cara guru harus berusaha mengelola kelas, menciptakan suasana belajar yang menyenangkan, menampilkan diri secara menarik dalam rangka membatu siswa termotivasi belajar.

\section{Unsur-unsur Dinamis Belajar}

Unsur-unsur dinamis dalam belajar adalah unsur yang keberadaannya dalam proses belajar yang tidak stabil, kadang lemah bahkan hilang sama sekali.

6. Upaya Guru Membelajarkan Siswa

Upaya yang dimaksud di sini adalah bagaimana guru mempersiapak diri dalam membelajarkan siswa mulai dari penguasaan materi, cara 
menyampaikannya, menarik perhatian siswa. ${ }^{25}$

Dapat dipahami dari pendapat di atas, faktor-faktor yang mempengaruhi adanya motivasi belajar akan membuat siswa semangat untuk mencapai tujuannya. Adanya unsur-unsur motivasi tersebut dapat memberikan energi, arahan dan dorongan terhadap perilaku untuk belajar.

\section{Aspek-Aspek Motivasi Belajar}

Menurut Chernis dan Goleman terdapat empat aspek dalam motivasi belajar, yaitu:

\section{1) Dorongan Mencapai Sesuatu}

Suatu kondisi dimana individu berjuang terhadap sesuatu untuk meningkatkan dan memenuhi standar atau kriteria yang ingin dicapai dalam belajar. Seorang individu melakukan aktivitas belajar karena adanya dorongan untuk mengetahui, memahami dan menguasai apa yang dipelajarinya.

2) Komitmen

Salah satu aspek penting dalam proses belajar adalah sebuah komitmen belajar. Siswa yang mempunyai komitmen dalam belajar, mengerjakan tugas pribadi dan kelompok tentunya mampu menyeimbangkan tugas mana yang harus didahulukan. Siswa yang mempunyai komitmen selalu merasa bahwa ia sebagai seorang siswa mempunyai tugas dan kewajiban yaitu belajar. Selain itu, ketika berkelompok siswa memiliki komitmen dan kesadaran untuk mengerjakan tugas bersama-sama. 3) Inisatif

Kesiapan untuk bertindak atau melakukan sesuatu atas peluang atau kesempatan yang ada. Inisiatif merupakan salah satu proses siswa dapat dilihat kemampuannya, misalnya siswa membiaskan diri belajar dan menyelesaikan tuganya tepat waktu tanpa adanya suruhan atau teguran dari orangtuanya. Siswa yang punya inisiatif merupakan siswa yang sudah memiliki pemikiran dan pemahaman sendiri dan melakukan sesuatu berdasarkan kesempatan yang ada. Ketika siswa menyelesaikan tugas, belajar untuk ujian, maka siswa memiliki kesempatan untuk memperluas pengetahuan serta dapat menyelesaikan hal lain yang lebih bermanfaat lagi.

4) Optimis

Optimis dapat dimaknai sebagai sikap yang gigih dalam upaya mencapai tujuan tanpa peduli adaya kegigihan dan kemunduran. Siswa yang mempunyai sikap optimis, tidak akan mudah menyerah dan putus asa, meskipun prestasinya kurang memuaskan. Misalnya, siswa mendapat nilai jelek, siswa tersebut akan selalu memiliki rasa optimis dalam dirinya dan terus belajar dengan lebih giat untuk mendapatkan nilai yang lebih baik. Optimis merupakan sikap yang seharusnya dimiliki oleh setiap siswa, agar siswa belajar bahwa kegagalan dalam belajar bukanlah suatu 
akhir belajar dan bukan berarti siwa itu merupakan siswa yang "bodoh" ${ }^{26}$

\section{Macam-macam Motivasi Belajar}

Menurut Muhibbin Syah, terdapat dua macam motivasi belajar yaitu:

1) Motivasi Intrinsik, adalah hal dan keadaan yang berasal dari diri siswa sendiri yang dapat mendorongnya melakukan tindakan belajar. Terdapat dalam motivasi intrinsik siswa adalah perasaan menyenangi materi dan kebutuhannya terhadap materi tersebut, misalnya untuk kehidupan masa depan siswa tersebut.

2) Motivasi Ekstrinsik, adalah hal dan keadaan yang datang dari luar individu yang juga mendorongnya untuk melakukan kegiatan belajar. Pujian dan hadiah, peraturan dan tata tertib sekolah, suri tauladan orang tua, guru dan seterusnya merupakan contoh-contoh konkret motivasi belajar ekstrinsik yang dapat mendorong siswa untuk belajar. ${ }^{27}$

\section{Pengertian Kecerdasan Spiritual}

Kecerdasan spiritual (SQ) menurut Danah Zohar dan Ian Marshall, sebagaimana yang dikutip oleh Ary Ginanjar adalah kecerdasan untuk menghadapi dan memecahkan persoalan makna dan nilai, yaitu kecerdasan untuk

\footnotetext{
${ }^{26}$ Sardiman, t., h. 86.

27 Muhibbin Syah, Psikologi Belajar, (Jakarta: Rajawali Press, 2013), h. 134.

28 Ary Ginanjar Agustian, , h. 57

29 Agus Nggermanto, (Quantum Quotient: Kecerdasan Quantum, Bandung: Yayasan Quantum, 2001), h. 117.
}

menempatkan perilaku dan hidup dalam konteks makna yang lebih luas dan kaya, kecerdasan untuk menilai bahwa tindakan atau jalan hidup seseorang lebih bermakna dibandingkan dengan yang lain. ${ }^{28}$

Menurut Sinetar yang dikutip oleh Agus Nggermanto, kecerdasan spiritual adalah kecerdasan yang mendapat inspirasi, dorongan, dan efektivitas yang terinspirasi, theis-ness atau penghayatan ketuhanan yang di dalamnya kita semua menjadi bagian. ${ }^{29}$

\section{Fungsi Kecerdasan Spiritual}

Kecerdasan spiritual telah ada sejak manusia dilahirkan, ini disandarkan pada proses peniupan ruh pada jasad manusia oleh Tuhan yang diikuti nilainilai spiritual Tuhan (sifar-sifat Tuhan) ke dalam jasad manusia tersebut. Sehingga dengan demikian tidak ada manusia yang tidak memiliki nilai-nilai spiritual, akan tetapi nilai spiritual ini masih berupa potensi yang perlu dikembangkan lebih lanjut. ${ }^{30}$

Kecerdasan Spiritual adalah kesadaran dalam diri manusia untuk menemukan mengembangkan bakatbakat bawaan, intuisi, otoritas batin, kemampuan memberadakan yang salah dan yang benar, serta kebijaksanaan. ${ }^{31}$ Kecerdasan spiritual melibatkan

${ }^{30}$ Dakir dan Sardimi, Pendidikan Islam dan ESQ Komparasi- Intregatif Upaya Menuju Stadium Insan Kamil, (Semarang: Rasail Media Group, 2011), h 56.

31 Zamroni dan Umairoh, (ESQ dan Model Kepemimpinan Pendidikan Kontruksi Sekolah Berbasis Spiritual, Semarang: Rasail Media Group, 2011), h. 13. 
kemampuan menghidupkan kebenaran yang paling dalam. Itu berarti mewujudkan hal yang terbaik, utuh, dan paling manusiawi dalam batin. Gagasan, energi, nilai, visi, dorongan, dan arah panggilan hidup, mengalir dari suatu keadaan kesadaran yang hidup bersama cinta. ${ }^{32}$

\section{Karakteristik Anak yang Memiliki} Kecerdasan Spiritual

Secara lebih rinci, karakteristik anak yang mempunyai kecerdasan spiritual dapat dilihat dari indikator sebagai berikut:

1) Merasakan Kehadiran Allah

Mereka yang bertanggung jawab dan cerdas secara ruhaniah, merasakan kehadiran Allah dimana saja mereka berada. Mereka meyakini bahwa salah satu produk dari keyakinannya beragama antara lain melahirkan kecerdasan spiritual yang menumbuhkan perasaan yang sangat mendalam (zauq) bahwa dirinya senantiasa berada dalam pengawasan Allah. ${ }^{33}$

2) Senang Menolong Orang Lain

Anak yang mempunyai kecerdasan spiritual tinggi akan senantiasa berbuat baik. Hal itu dibuktikan dengan sikapnya yang senang menolong orang lain. ${ }^{34}$ Karena, didalam dirinya telah tumbuh rasa empati yang memungkinkan anak

32 Marsha Sinetar, Spiritual Intelligence, Kecerdasan Spiritual: Belajar dari Anak yang Mempunyai Kesadaran Diri, (Jakarta: PT Gramedia, 2000), h. 15.

33 Toto Tasmara, Kecerdasan Ruhaniah, (Transendental Intelligence), Membentuk Kepribadian yang Bertanggung jawab, Profesional dan Berakhlak, (Jakarta: Gema Insani, 2001), h. 14.

${ }^{34}$ Akhmad Muhaimin Azzed, $h .52$. untuk dapat merasakan kondisi batin orang lain. ${ }^{35}$

3) Bertanggung Jawab

Dalam Islam, pertanggung-jawaban merupakan salah satu dasar dari keyakinan agama. hal ini persis seperti hukum aksi-reaksi atau hukum sebabakibat yang bersifat universal. Setiap pribadi manusia harus bertanggung jawab terhadap apa yang dimilikinya, maupun segala perbuatan yang dilakukannya. ${ }^{36}$

4) Jujur

Kejujuran adalah tiang penopang segala persoalan. ${ }^{37}$ Salah satu dimensi kecerdasan ruhani terletak pada nilai kejujuran yang merupakan mahkota kepribadian orang-orang yang mulia. Kejujuran merupakan komponen rohani yang menentukan berbagai sikap terpuji (honorable, creditable, respectable, maqamam mahmudah). ${ }^{38}$

5) Disiplin dan Sungguh-sungguh

Menghargai waktu dan bersikap sungguh- sungguh dalam mengerjakan kebaikan merupakan ciri-ciri Muslim yang memiliki kecerdasan spiritual yang tinggi. ${ }^{39}$ Disiplin adalah suatu tata tertib yang dapat mengatur tatanan kehidupan pribadi dan kelompok. Disiplin timbul

35 Toto Tasmara h. 30.

36 Syahmuharnis, Harry Sidharta, TQ Transcendental Quotient Kecerdasan Diri Terbaik, Jakarta: Penerbit Republika, 2006, h. 176.

${ }^{37}$ Syahmuharnis, Harry Sidharta,

${ }^{38}$ M. Abdul Qadir Abu Faris, Menyucikan Jiwa, Terj. Habiburrahman Saerozi, Jakarta: Gema Insani, 2006, h. 306.

39 Syahmuharnis, Harry Sidharta, h178. 
dari dalam jiwa karena adanya dorongan untuk menaati tata tertib tersebut. ${ }^{40}$

\section{Pembahasan}

Berdasarkan uji hipotesis diperoleh: 1) ada pengaruh yang signifikan antara motivasi belajar terhadap pelaksanaan program Tahfidz Al Qur'an, 2) ada pengaruh yang signifikan antara kecerdasan spiritual terhadap pelaksanaan program Tahfidz Al Qur'an, 3) ada pengaruh motivasi belajar dan kecerdasan spiritual terhadap pelaksanaan program tahfidz Al Qur'an.

Pelaksanaan program Tahfidz Al Qur'an dilakukan siswa secara bertahap sesuai waktu yang ditentukan guna mencapai target minimal hafal satu juz selama menempuh pendidikan di kelas 7 dan 8. Program ini menggunakan metode khusus yang disesuaikan dengan tingkat umur dan psikologi anak, yakni menggunakan metode wahdah, metode sima'i dan metode jama'. Metode wahdah merupakan metode menghafal satu persatu terhadap ayat-ayat yang hendak dihafal di mana setiap ayat di ulang sebanyak 10 kali atau lebih sehingga benar- benar membentuk gerak reflek pada lisannya setelah benr-benar telah hafal dapat dilanjutkan ayat berikutnya. Metode sima'i adalah metode dengan cara mendengarkan suara bacaan untuk dihafalkannya, baik mendengarkan dari guru yang membimbingnya ataupun dari rekaman. Metode jama' yaitu bersama- sama atau cara menghafal yang dilakukan secara kolektif atau bersamasama dipimpin oleh guru. Kegiatan Tahfidz Al Qur'an dilaksanakan setiap hari selasa sampai dengan Hari Kamis dimulai pukul 06.30 WIB sebelum kegiatan pembelajaran dimulai, sedangkan setoran hafalan dilakukan pada Hari Jum'at dan Sabtu. Pelaksanaan program tahfidz Al Qur'an tidak dapat dilepaskan dari faktor-faktor yang mempengaruhinya. Hasil analisis data menunjukkan bahwa motivasi belajar dan kecerdasan spiritua secara bersamasama memiliki pengaruh terhadap pelaksanaan program Tahfidz Al Qur'an. Callahan dan Clark mengemukakan bahwa motivasi merupakan tenaga pendorong atau penarik yang menyebabkan munculnya tingkah laku ke arah suatu tujuan tertentu. Peserta didik akan belajar dengan sungguhsungguh apabila memiliki motivasi yang tinggi. ${ }^{41}$ Siswa bermotivasi tinggi mempunyai kondisi psikologis yang mendorong dirinya untuk belajar dengan sunguh-sungguh yang pada waktunya akan berbentuk cara belajar yang sistematis, penuh konsentrasi dan dapat menyeleksi kegiatan-kegiatannya. Motivasi intrinsik sangat diperlukan terutama jika belajar sendiri. Keinginan itu dilatar belakangi oleh pemikiran positif, bahwa semua mata pelajaran yang dipelajari sekarang akan dibutuhkan dan sangat berguna di masa

41 E. Mulyasa, Kurikulum Berbasis Kompetensi Konsep Karakteristik dan Implementasi, (Bandung: PT. Remaja Rosdakarya, 2002), h. 112. 
kini dan mendatang. Selain motivasi intrinsik, individu membutuhkan motivasi ekstrinsik yakni berupa dorongan dan rangsangan dari luar, khusunya dari apa yang ada disekitarnya. Siswa yang mempunyai motivasi belajar tinggi akan terus berupaya dan berusaha dengan gigih untuk mencapai tujuan yang telah ditetapkan. Ketika siswa sudah mempunyai tujuan dari belajarnya ia juga akan lebih sungguh-sungguh, berkonsntrasi, dan menganggap setiap kegiatan belajarnya menjadi hal yang menyenangkan. Penelitain ini juga mendapatkan temuan bahwa siswa-siswa yang mempunyai motivasi belajar baik menunjukkan sikap positif seperti datang tepat waktu dalam mengikuti kegiatan tahfidz Al Qur'an, mempunyai jadwal khusus untuk belajar, memperhatikan penjelasan dari guru daripada mengobrol dengan teman atau bermain handphone, dan mempunyai inisiatif menyelesaikan materi yang belum difahami.

Kecerdasan spiritual menurut Sinetar yang dikutip oleh Agus Nggermanto, adalah kecerdasan yang mendapat inspirasi, dorongan, dan efektivitas yang terinspirasi, theis-ness atau penghayatan ketuhanan yang di dalamnya kita semua menjadi bagian. ${ }^{42}$ Kecerdasan spiritual merupakan kemampuan untuk memaknai setiap perilaku dan aspek kehidupan berdasarkan dengan nilai ibadah kepada Allah dalam kaitannya untuk mencapai kebahagiaan dunia dan akhirat. Siswa yang memiliki kecerdasan spiritual baik ia akan menujukkan karakter-karakter yang baik pula, seperti merasakan kehadiran Allah, senang menolong orang lain, bertanggungjawab, jujur, disiplin dan sungguh-sungguh. Penelitain ini juga mendapatkan temuan bahwa siswasiswa yang mempunyai kecerdasan spiritual baik menunjukkan sikap positif seperti selalu menyelesaikan tugas yang diberikan oleh guru, menjaga ucapan dari perkataan yang tidak baik, melaksanakan shalat fardlu tepat waktu, gemar memberikan pertolongan terhadap teman, berbusana rapi, sopan dan menutup aurat, dan mentaati peraturan sekolah.

Penelitian ini menunjukkan bahwa motivasi belajar dan kecerdasan spiritual berpengaruh terhadap pelaksanaan program tahfidz Al Qur'an di SMP Negeri 1 Wungu. Tanpa adanya motivasi yang kuat siswa tidak akan sungguhsungguh dalam melaksanakan hafalannya, sebaliknya ketika siswa mempunyai motivasi yang baik ia akan semakin bersemangat dalam menghafal dan menyelesaikan target hafalan yang sudah diprogramkan. Begitu juga dalam melaksanakan program tahfidz $\mathrm{Al}$ Qur'an, tanpa adanya kecerdasan spiritual tentu siswa akan mengalami kesulitan, karena hafalan Al Qur'an tidak hanya urusan lahiriyah namun juga batiniyah. Siswa yang menghafalkan Al

42 Agus Nggermanto, Quantum Quotient: 
Qur'an membutuhkan ketenangan jiwa, dan ketenangan jiwa ini didapatkan dengan cara membiasakan perilakuperilaku baik dalam aktivitasnya. Siswa yang terganggu ketenangan jiwanya akan mengakibatkan sulitnya menghafalkan ayat-ayat Al Qur'an

Pengaruh antara motivasi belajar dan kecerdasan spiritual terhadap pelaksanaan program tahfidz Al Qur'an didukung oleh hasil SPSS 25 For Windows menggunakan regresi linier ganda pada tabel IV.8 yang menyatakan bahwa sig. T variabel motivasi belajar sebesar 0,018 dan sig. $\mathrm{T}$ variabel kecerdasan spiritual sebesar 0,000.

Penelitian ini juga dinyatakan valid dan reliabel, hal ini dapat dilihat dari data yang terlampir (lampiran) bahwa seluruh item dari motivasi belajar, kecerdasan spiritual dan pelaksanaan program tahfidz Al Qur'an yang masing-masing berjumlah 20 butir item dinyatakan valid. Dikatakan valid karena nilai $r$ hitung lebih besar dari nilai $r$ tabel $(0,361)$. Hasil uji reliabilitas variabel motivasi belajar diperoleh nilai reliabilitas sebesar 0,907, variabel kecerdasan spiritual diperoleh nilai reliablitas sebesar 0,910 , dan variabel program tahfidz diperoleh nilai 0,938.

Hasil analisis regresi juga menunjukkan bahwa keragaman hasil program tahfidz Al Qur'an dipengaruhi oleh $74,7 \%$ variabel bebas motivasi belajar dan kecerdasan spiritual. Sedangkan keragaman sisanya yaitu sebesar 25,3\% dipengaruhi oleh variabel lain diluar variabel yang diteliti. Variabel yang paling dominan mempengaruhi pelaksanaan program tahfidz Al Qur'an adalah variabel kecerdasan spiritual. Terlihat pada tabel IV.8 bahwa variabel yang memiliki koefesien beta tertinggi terdapat pada variabel kecerdasan spiritual dengan nilai koefsisen beta sebesar 0,684 .

\section{Kesimpulan}

Berdasarkan hasil penelitian yang berjudul Pengaruh Motivasi Belajar dan Kecerdasan Spiritual Terhadap Pelaksanaan Program Tahfidz Al Qur'an di SMP Negeri 1 Wungu Kabupaten Madiun dapat disimpulkan sebagai berikut:

1. Ada pengaruh positif yang signifikan motivasi belajar terhadap pelaksanaan program tahfidz Al Qur'an. Hal ini ditunjukkan dengan nilai $t_{\text {hitung }}$ sebesar 2,417 lebih besar dari $t_{\text {tabel }}$ dan signifikan sebesar 0,018. $t_{\text {hitung }}>t_{\text {tabel }}$ $(2,417>1,993)$ atau sig. $\mathrm{T}<5 \%(0,018<$ $0,05)$. Siswa-siswa yang mengikuti program Tahfidz Al Qur'an menunjukkan sikap positif seperti datang tepat waktu dalam mengikuti kegiatan Tahfidz Al Qur'an, mempunyai jadwal khusus untuk belajar, memperhatikan penjelasan dari guru daripada mengobrol dengan teman atau bermain handphone, dan mempunyai inisiatif menyelesaikan materi yang belum difahami.

2. Ada pengaruh positif yang signifikan kecerdasan spiritual terhadap pelaksanaan program Tahfidz Al Qur'an. Hal ini ditunjukkan dengan

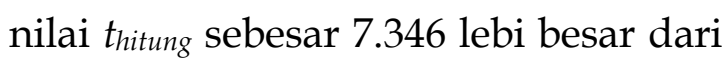


$t_{\text {tabel }}$ dan signifikan sebesar 0,000. thitung $>t_{\text {tabel }}(7.346>1.993)$ atau sig. $\mathrm{T}<5 \%$ $(0,000<0,05)$. Siswa-siswa yang mengikuti program Tahfidz Al Qur'an menunjukkan sikap positif seperti selalu menyelesaikan tugas yang diberikan oleh guru, menjaga ucapan dari perkataan yang tidak baik, melaksanakan shalat fardlu tepat waktu, gemar memberikan pertolongan terhadap teman, berbusana rapi, sopan dan menutup aurat, dan mentaati peraturan sekolah.

3. Ada pengaruh positif yang signifikan motivasi belajar dan kecerdasan spiritual secara bersama-sama terhadap pelaksanaan program Tahfidz Al Qur'an. Hal ini ditunjukkan dengan nilai $F_{\text {hitung }}$ sebesar 105.558, nilai ini lebih besar dari $F_{\text {tabel }}(105,558>$ $3,13)$ dan nilai sig. F $(0,000)$ lebih kecil dari 0,05 . Siswa-siswa yang mengikuti program Tahfidz Al Qur'an menunjukkan sikap positif seperti menyimak bacaan Al Qur'an dan penjelasan guru, mempunyai jadwal khusus untuk membaca dan menghafalkan Al Qur'an, senang mendengarkan bacaan atau hafalan dari orang lain, baik dari guru ataupun teman, dan optimis menghafalkan $\mathrm{Al}$ Qur'an bersama teman. 


\section{Daftar Pustaka}

Agustian, Ary Ginanjar. Rahasia Sukses Membangun Kecerdasan Emosi dan Spiritual (ESQ), Jakarta: Penerbit Arga, 2001

Badwilan, Ahmad Salim. Panduan Cepat menghafal Al-Qur'an, Jogjakarta: DIVA Press, 2009

Baharuddin dan Wahyuni, Esa Nur. "Teori Belajar dan Pembelajaran", Yogyakarta: Ar Ruz Media, 2015

Dakir dan Sardimi, Pendidikan Islam dan ESQ Komparasi- Intregatif Upaya Menuju Stadium Insan Kamil, Semarang: Rasail Media Group, 2011

Desmita, Psikologi Perkembangan, Bandung: PT Remaja Rosdikarya, 2010

Dimyati dan Mudjiono, Belajar dan Pembelajaran, Jakarta: Rineka Cipta, 2001

E. Mulyasa, Kurikulum Berbasis Kompetensi Konsep Karakteristik dan Implementasi, Bandung: PT. Remaja Rosdakarya, 2002

Faris, M. Abdul Qadir Abu. Menyucikan Jiwa, Terj. Habiburrahman Saerozi, Jakarta: Gema Insani, 2006

Fuad A. Jauhar and Sujianto, Agus Eko. Analisis Statistik Dengan Program SPSS Tulungagung: Cahaya Abadi, 2014

Hamzah. B. Uno, Teori Motivasi EPengukurannya Analisis di Bidang Pendidikan: Analisis di Bidang
Pendiddikan, Jakarta: Bumi Aksara, 2014

Kementerian Agama Republik Indonesia, Al-Qur'an Al-Karim dan Terjemahnya, Al Halim, Surabaya: Halim Publishing \& Distributing, 2014

Mahfud, Rois. Al-Islam: Pendidikan Agama Islam, Jakarta: Penerbit Erlangga, 2011

Meggit, Carolyn, Memahami Perkembangan Anak, Jakarta: PT Indeks, 2013.

Nawawi, Rif'at Syauqi. Kepribadian Qur'ani, Jakarta: Amzah, 2011

Nggermanto, Agus. Quantum Quotient: Kecerdasan Quantum, Bandung: Yayasan Quantum, 2001

Prawira, Purma Atmaja. Psikologi Pendidikan dalam Perspektif Baru, Yogyakarta: Ar Ruz Media, 2012

S. Arikunto, Manajemen Penelitian. Jakarta: Rineka Cipta, 1998

Sa'ad Riyadh, Anakku, Cintailah AlQur'an, Jakarta: Gema Insani, 2009

Sardiman A. M. , Interaksi \& Motivasi Belajar Mengajar, Jakarta: Raja Grapindo Persada, 2010

Sinetar, Marsha. Spiritual Intelligence, Kecerdasan Spiritual: Belajar dari Anak yang Mempunyai Kesadaran Diri, Jakarta: PT Gramedia, 2000

Sukidi, Rahasia Sukses Hidup Bahagia Kecerdasan Spiritual mengapa SQ lebih Penting daripada IQ dan EQ, Jakarta: PT Gramedia Pustaka Utama, 2002 
Susanto, Ahmad. Perkembangan Anak Usia Dini, Jakarta: Kencana, 2011

Syah, Muhibbin. Psikologi Belajar, (Jakarta: Rajawali Press, 2013

Syahmuharnis, Harry Sidharta, TQ Transcendental Quotient Kecerdasan Diri Terbaik, Jakarta: Penerbit Republika, 2006

Syofian, Siregar. Metode Penelitian Kuantitatif. Jakarta: Prenadamedia Group. 2013

Tasmara, Toto. Kecerdasan Ruhaniah, (Transendental Intelligence), Membentuk Kepribadian yang Bertanggung jawab, Profesional dan Berakhlak, Jakarta: Gema Insani, 2001

Yamin, Martinis. Strategi Pembelajaran Berbasis Kompetensi, Ciputat: Gaung Persada Press, 2003

Zamroni dan Umairoh, (ESQ dan Model Kepemimpinan Pendidikan Kontruksi Sekolah Berbasis Spiritual, Semarang: Rasail Media Group, 2011 